\title{
PENGARUH SUBTITUSI PUPUK N SINTETIK DENGAN LIMBAH LUMPUR SAWIT TERHADAP PERTUMBUHAN DAN HASIL JAGUNG MANIS
}

\author{
Johannes Simbolon ${ }^{1}$, Bilman Wilman Simanihuruk ${ }^{1 *}$, Bambang Gonggo Murcitro ${ }^{2}$, \\ Herry Gusmara ${ }^{2}$, Eko Suprijono ${ }^{1}$ \\ ${ }^{1}$ Program Studi Agroekoteknologi, Fakultas Pertanian Universitas Bengkulu, \\ 2 Program Studi Ilnu Tanah, Fakultas Pertanian Universitas Bengkulu, \\ * Corresponding Author: bilmanwilmansimanihuruk@yahoo.co.id
}

\begin{abstract}
[EFFECTS OF PALM OIL SLUDGE SUBTITUTION FOR SYNTHETIC N FERTILIZER ON GROWTH AND YIELD OF SWEET CORN]. Palm oil sludge (POS) contains high concentrations of organic nitrogen dan its can serve as an alternative for synthetic nitrogen fertilizer. Objective of this study was to compare the growth and yield of sweet corn as amended with different compositions of synthetic $\mathrm{N}$ fertilizer and palm oil sludge. Six compositions, each containing $138 \mathrm{~kg} \mathrm{~N} /$ ha were assigned as the treatment and arranged in a randomized complete block design with three replications. These were $100 \%$ synthetic fertilizer, $80 \%$ synthetic fertilizer $+20 \%$ POS, $60 \%$ synthetic fertilizer + $40 \%$ POS, $40 \%$ synthetic fertilizer $+60 \%$ POS, $20 \%$ synthetic fertilizer $+80 \%$ POS, and $100 \%$ POS. The results of this study indicated that the plot amended with $60 \%$ synthetic fertilizer $+40 \%$ POS produced the highest plant stature $(176.4 \mathrm{~cm})$, stem diameter $(2.40 \mathrm{~cm})$, leaf area $\left(8712.82 \mathrm{~cm}^{2}\right)$, plant fresh weight $(375.19 \mathrm{~g})$, plant dry weight $(136.68$ $\mathrm{g}$ ), and husked ear length $(17.93 \mathrm{~cm})$. However, the highest observed husked ear yield was only about $61.6 \%$ the yield potential of the sweet corn variety.
\end{abstract}

Keyword: sweet corn, palm oil sludge, synthetic fertilizer, nitrogen

\begin{abstract}
ABSTRAK
Lumpur sawit (LS) mengandung nitrogen organik dengan konsentrasi tinggi dan dapat digunakan sebagai pengganti pupuk nitrogen sintetik. Tujuan dari penelitian ini adalah untuk membandingkan pertumbuhan dan hasil jagung manis yang dipupuk dengan pupuk $\mathrm{N}$ sintetis dan lumpur sawit dengan komposisi berbeda. Perlakuan yang yang terdiri atas enam komposisi, masing-masing mengandung $138 \mathrm{~kg} \mathrm{~N} /$ ha, disusun dalam rancangan acak kelompok lengkap dengan tiga ulangan. Perlakuan tersebut adalah $100 \%$ pupuk sintetik, $80 \%$ pupuk sisntetik $+20 \%$ LS, $60 \%$ pupuk sisntetik + $40 \%$ LS, 40\% pupuk sisntetik $+60 \%$ LS, 20\% pupuk sisntetik $+80 \%$ LS, dan $100 \%$ LS. Hasil penelitian menunjukkan bahwa petak yang dipupuk dengan $60 \%$ pupuk sintetik $+40 \%$ LS menghasilkan tinggi tanaman $(176,4$ $\mathrm{cm})$, diameter batang $(2,40 \mathrm{~cm})$, luas daun $\left(8712,82 \mathrm{~cm}^{2}\right)$, bobot berangkasan segar $(375,19 \mathrm{~g})$, bobot berangkasan kering $(136,68 \mathrm{~g})$, dan panjang tongkol tanpa kelobot $(17,93 \mathrm{~cm})$ tertinggi. Namun demikian, hasil tongkol tanpa kelobot tertinggi hanya mencapai $61,6 \%$ dari potensi hasil varietas jagung manis yang digunakan.
\end{abstract}

Kata kunci : jagung manis, lumpur sawit, pupuk sintetik, nitrogen 


\section{PENDAHULUAN}

Jagung manis (Zea mays saccharata Sturt L) dikategorikan sebagai tanaman serealia yang banyak disukai oleh masyarakat karena mempunyai rasa manis yang berasal dari kandungan gula yang tinggi. Tanaman ini mulai dikenal di Indonesia sejak awal tahun 1980 yaitu melalui hasil penelitian yang menyilangkan jagung tipe flint (jagung mutiara) dan jagung tipe dent (jagung gigi kuda) (Beckingham, 2007). Pertumbuhan tanaman jagung manis mirip dengan tanaman jagung biasa, namun tanaman ini dapat dipanen lebih awal dengan umur produksi lebih singkat (genjah) yaitu pada umur 65-75 hari. Selain itu tanaman ini dapat ditanam di daerah beriklim tropis seperti Indonesia (Syukur \& Rifianto, 2013).

Salah satu prospek masa depan dari budidaya jagung manis ialah nilai ekonomis yang tinggi. Hal ini didorong dengan kandungan gizi yang baik bagi kesehatan manusia terutama untuk mengontrol berat badan (obesitas) dan mencegah penyakit diabetes (Santoso, 2011). Sesuai dengan hasil penelitian Ariyanto (2011) menunjukkan bahwa pada $100 \mathrm{~g}$ biji jagung manis mengandung 22,8 g karbohidrat, $96 \mathrm{kkal}$, $3,5 \mathrm{~g}$ protein, $1 \mathrm{~g}$ lemak, 400 SI vitamin A, $0,15 \mathrm{mg}$ vitamin $\mathrm{B}, 12 \mathrm{mg}$ vitamin $\mathrm{C}, 0,7 \mathrm{mg}$ besi, $111 \mathrm{mg}$ fosfor, $3 \mathrm{mg}$ kalsium, dan 72,7 $\mathrm{g}$ air.

Berdasarkan kandungan gizinya maka permintaan kebutuhan konsumsi masyarakat Indonesia semakin meningkat. Menurut data Badan Pusat Statistik (2015) tercatat bahwa produksi jagung manis nasional tiap tahunnya mengalami peningkatan. Pada tahun 2014 produksi jagung sebesar 1.159 .795 ton, dan pada tahun 2015 dan 2016 yaitu 1.519.407 ton dan 1.557.462 ton (BPS, 2017). Produksi yang besar ternyata belum cukup untuk memenuhi kebutuhan konsumsi masyarakat. Oleh karena itu, sudah seharusnya dilakukan upaya agar produksi dapat meningkat sesuai kebutuhan pasar (Agustyari et al., 2013).

Permintaan pasar yang menginginkan produk dengan kualitas dan kuantitas terbaik, menyebabkan pertanian saat ini masih bergantung pada penggunaan pupuk sintetik yang memiliki banyak kelemahan. Perbaikan budidaya sudah seharusnya dilakukan terutama dengan memilih benih varietas unggul dan teknik pemupukan yang tepat. Teknik pemupukan pada umumnya terdiri atas waktu aplikasi, dosis, dan jenis pupuk yang digunakan. Adapun jenis pupuk yang dapat digunakan yaitu pupuk organik dan pupuk anorganik (Sutanto, 2002).

Penggunaan pupuk kimia sintetik apabila digunakan secara tidak tepat maka dapat menyebabkan dampak negatif yang berkepanjangan, salah satu dampak negatif yang ditimbulkan ialah menurunnya kemampuan tanah dalam menyimpan air (Lestari, 2009). Salah satu upaya yang dapat dilakukan untuk memperbaiki tanah yang rusak adalah dengan penggunaan pupuk organik sebagai pembenah tanah yang dapat memperbaiki sifat fisik, kimia, dan biologi tanah (Prasetyo et al., 2013 ; Marpaung, 2014). Pemberian pupuk sintetik dengan dosis yang berlebihan dapat menekan populasi mikroba tanah dan menyebabkan kerusakan lingkungan (Lestari, 2009). Oleh karena itu, untuk mengurangi dampak penggunaan pupuk sintetik yang diberikan dapat digantikan dengan pupuk organik. Penggunaan pupuk organik diyakini dapat meningkatkan pertumbuhan dan hasil tanaman, serta menjaga kelestarian tanah (Asbur \& Purwaningrum, 2015).

Lumpur sawit dapat digunakan sebagai sumber pupuk organik terutama di Provinsi Bengkulu yang saat ini mencari solusi dalam upaya meningkatkan hasil produksi jagung manis (Handajaningsih, 2010). Pada umumnya, limbah pabrik kelapa sawit yang berupa lumpur sawit selama ini hanya terbuang dan terbengkalai dengan jumlah yang melimpah. Bahanbahan organik ini dapat menimbulkan pencemaran dan kerusakan lingkungan karena dapat mengeluarkan gas methan. Limbah padat pabrik kelapa sawit dikelompokkan menjadi beberapa jenis yaitu limbah yang berasal dari proses pengolahan tandan kosong kelapa sawit, cangkang atau tempurung, serabut atau serat, dan lumpur sawit (Wahyono et al., 2008).

Lumpur sawit merupakan limbah padat yang dihasilkan dari kegiatan Pabrik Kelola Kelapa Sawit (PKKS) berupa larutan buangan yang diperoleh dari sistem decanter dengan proses pemerasan tandan buah segar, pemurnian minyak (Clarification), dan hasil ekstraksi minyak (Said, 1996). Lumpur sawit yang dihasilkan dari sistem decanter dialirkan melalui kolam anaerob II dalam IPAL akan diinkubasi dalam waktu yang lama. Kandungan unsur hara yang terdapat pada lumpur sawit yaitu: C-Organik $5,52 \%, \mathrm{C} / \mathrm{N} 30,81, \mathrm{~N}$-total $0,18 \%$, P-total $0,07 \%$, K $0,06 \%$, COD $10082 \mathrm{mg} / \mathrm{L}$, BOD $7333 \mathrm{mg} / \mathrm{L}$, TSS $7928 \mathrm{mg} / \mathrm{L}$, dan nilai pH 6,1 (Nursanti et al., 2013). Berdasarkan kandungan unsur-unsur tersebut lumpur sawit berpotensi untuk digunakan sebagai pupuk organik (Pramana \& Amri, 2016).

Menurut Jenny \& Suwadji (1999), dan Pradipta et al. (2017) lumpur sawit yang telah diaplikasikan ke dalam tanah dapat memperbaiki kesuburan tanah, menambah daya serap air dan menjadi sumber energi bagi mikroba tanah. Hasil penelitian Pandapotan et al. (2017) menunjukkan bahwa pemupukan jagung manis menggunakan lumpur sawit sebanyak 21,25 ton/ha di lahan ultisol dapat meningkatkan kandungan unsur hara tanah, $\mathrm{pH}$ tanah, C-organik, $\mathrm{P}$ tersedia, tinggi tanaman, jumlah daun, diameter batang, berat kering tajuk, dan serapan P. Hasil penelitian Darmawati et al. (2014) menunjukkan bahwa pemupukan menggunakan lumpur sawit dengan dosis 34 ton/ha dapat memberikan pengaruh nyata pada variabel hasil tanaman yang meliputi panjang tongkol sebesar $21,23 \mathrm{~cm}$, 
diameter tongkol 4,29 g, berat tongkol 3,90 g, dan berat tongkol per plot $\left(1,5 \mathrm{~m}^{2}\right)$ sebesar $4,17 \mathrm{~kg}$. Hasil penelitian Made (2010) menunjukkan bahwa pemberian pupuk urea $300 \mathrm{~kg} /$ ha berpengaruh nyata terhadap diameter batang, panjang tongkol, dan jumlah biji per tongkol.

Penelitian ini bertujuan untuk membandingkan pertumbuhan dan hasil jagung manis yang dipupuk dengan pupuk $\mathrm{N}$ sintetis dan lumpur sawit dengan komposisi berbeda.

\section{METODE PENELITIAN}

Penelitian ini telah dilaksanakan dari bulan Maret sampai Mei 2018 di Desa Pasar Pedati, Kecamatan Pondok Kelapa, Kabupaten Bengkulu Tengah, dengan ketinggian tempat sekitar $15 \mathrm{~m}$ dpl. Rancangan Acak Kelompok Lengkap (RAKL) dengan satu faktor yaitu komposisi persentase pengurangan $\mathrm{N}$ sintetik yang disubtitusi lumpur sawit dengan 6 taraf perlakuan dan 4 ulangan, digunakan untuk menempatkan 24 satuan percobaan. Adapun perlakuan komposisi persentase pengurangan $\mathrm{N}$ sintetik yang disubtitusi lumpur sawit adalah sebagai berikut : $100 \% \mathrm{~N}$ (setara $138 \mathrm{~kg} / \mathrm{ha}$ ) $+0 \% \mathrm{LS} ; 80 \%$ $\mathrm{N}$ (setara $110,4 \mathrm{~kg} / \mathrm{ha})+20 \% \mathrm{LS}$ (setara $27,6 \mathrm{~N}$ $\mathrm{kg} / \mathrm{ha}) ; 60 \% \mathrm{~N}$ (setara 82,8 kg/ha) $+40 \% \mathrm{LS}$ (setara 55,2 N kg/ha); $40 \% \mathrm{~N}$ (setara 55,2 kg/ha) + $60 \%$ LS (setara 82,8 N kg/ha); $20 \% \mathrm{~N}$ (setara 27,6 $\mathrm{kg} / \mathrm{ha})+80 \% \mathrm{LS}$ (setara 110,4 N kg/ha); $0 \% \mathrm{~N}+$ $100 \%$ LS (setara $138 \mathrm{~kg} / \mathrm{ha}$ )

Tahap awal penelitian ini diawali dengan melakukan analisis tanah sebelum penanaman, dilakukan terhadap kadar $\mathrm{N}, \mathrm{P}, \mathrm{K}, \mathrm{pH}, \mathrm{Al}_{\mathrm{dd}}$ dan C-Organik. Pengolahan lahan dilakukan sebanyak dua kali. Pengolahan lahan pertama dilakukan pada saat dua minggu sebelum tanam dan kedua dilakukan satu minggu sebelum tanam dengan menggemburkan tanah menggunakan cangkul. Petakan dibuat sebanyak 24 petak yang masing-masing berukuran 3,5 $\mathrm{m}$ x 3,5 $\mathrm{m}$ dengan jarak antar petak $30 \mathrm{~cm}$ dan jarak antar ulangan $1 \mathrm{~m}$. Setiap petakan diberi dolomit sebanyak 1,5 ton/ha (Yulianti et al., 2016) dan lumpur sawit yang ditabur pada 1 minggu sebelum tanam dengan cara dicampur merata dengan tanah. Benih yang digunakan pada penelitian ini merupakan benih jagung manis varietas Jambore.

Benih jagung manis ditanam secara tugal pada kedalaman $5 \mathrm{~cm}$. Pada setiap lubang tanam diisi 2 benih jagung manis dan diberi carbofuran, jarak tanam antar lubang yaitu $70 \mathrm{~cm} \times 25 \mathrm{~cm}$ (Syukur \& Rifianto, 2013). Tanaman sampel dipilih dari 10\% total populasi tiap percobaan dan bukan tanaman pinggir sehingga diperoleh 7 tanaman per petak.

Aplikasi pupuk Urea dilakukan sesuai perlakuan dan saat tanaman telah memiliki 3-4 helai daun. Pemupukan dilakukan sebanyak 2 kali yaitu pada saat tanaman berumur 7 hst dan 35 hst. Pupuk dasar yang diberikan berupa SP-36 $250 \mathrm{~kg} / \mathrm{ha}$ dan $\mathrm{KCl} 75 \mathrm{~kg} / \mathrm{ha}$ ketika tanaman berumur 35 hst dan sesuai anjuran dengan cara ditabur pada larikan yang berjarak $10 \mathrm{~cm}$ dari tanaman (Syofia et al., 2015).

Peubah yang diamati pada fase vegetatif meliputi : tinggi tanaman $(\mathrm{cm})$, jumlah daun (helai) diameter batang $(\mathrm{cm})$, dan kehijauan daun diukur 5 kali pengamatan ( $2 \mathrm{mst}, 3 \mathrm{mst}, 4 \mathrm{mst}, 5 \mathrm{mst}$ dan 6 $\mathrm{mst})$; luas daun $\left(\mathrm{cm}^{2}\right)$ diperoleh dengan melakukan pengukuran sebanyak 1 kali yaitu pada masa vegetatif akhir dengan menggunakan meteran. Daun yang diamati adalah daun ke empat (di bawah tongkol jagung manis) dengan menggunakan metode panjang kali lebar ( $\mathrm{p}$ x $1(0,731)$ dan dikali jumlah daun dalam satu tanaman sampel (Susilo, 2015). Peubah yang diamati pada fase generatif meliputi : bobot tongkol tanpa kelobot $(\mathrm{g})$; panjang tongkol tanpa kelobot $(\mathrm{cm})$; bobot tongkol berkelobot per petak $(\mathrm{kg})$; hasil per petak $(\mathrm{kg})$; bobot berangkasan segar $(\mathrm{g})$; dan bobot berangkasan kering $(\mathrm{g})$.

Data peubah pertumbuhan dan hasil jagung manis yang dikumpulkan dianalisis secara statis-tik dengan analisis varian (ANAVA) menggunakan uji $\mathrm{F}$ pada taraf $5 \%$. Untuk membandingkan rata-rata antar perlakuan digunakan uji BNT pada taraf $5 \%$ (Gomez \& Gomez, 1984).

\section{HASIL DAN PEMBAHASAN}

Karakteristik tanah menunjukkan bahwa tanah bertekstur lempung liat berpasir (sandy clay loam) yang memiliki pH 4,9 (masam), kandungan C-organik tergolong rendah sebesar 2,05\%, kandungan N-total tergolong rendah yaitu sebesar $0,15 \%$, kandungan K-dd tergolong rendah sebesar $0,16 \mathrm{me} / 100 \mathrm{~g}$, kandungan Al-dd yang tinggi sebesar 1,65 me/100 g, dan kandungan $\mathrm{P}_{2} \mathrm{O}_{5}$ sebesar 4,33 ppm. Jika dilihat dari data tersebut, maka tanah yang digunakan pada penelitian ini tergolong dalam kriteria tanah yang kurang subur (BPPP, 2005).

Selama penelitian berlangsung, curah hujan berkisar $163 \mathrm{~mm}$ sampai $421 \mathrm{~mm}$ dengan angka total curah hujan sebesar $1258 \mathrm{~mm}$. Curah hujan ini mencukupi untuk kebutuhan air bagi pertumbuhan tanaman jagung yang berkisar $700-800 \mathrm{~mm}$ atau $300 \mathrm{~mm}$ selama fase vegetatif dan 400-500 mm untuk fase generatif (Muamar et al., 2012). Berdasarkan data curah hujan tersebut maka dapat disimpulkan bahwa ketersediaan air untuk pertumbuhan jagung manis sudah tercukupi. Pada saat jagung manis berumur 2 mst sampai 6 mst tanaman jagung diserang oleh hama belalang, ulat, dan kutu daun. Tindakan pengendalian dilakukan dengan menyemprotkan insektisida berbahan aktif karbaril. Setelah dilakukan penyemprotan tingkat kerusakan akibat serangan hama dapat ditekan. Panen jagung manis dilakukan pada umur 75 hst ditandai dengan adanya perubahan warna pada rambut tongkol yang 
berwarna hijau kekuning-kuningan menjadi cokelat dan bila tongkol dipegang terasa bijinya sudah penuh.

Hasil analisis data variabel pertumbuhan vegetatif dan hasil jagung manis dengan pengurangan $\mathrm{N}$ sintetik yang disubstitusi lumpur sawit berpengaruh nyata terhadap peubah tinggi tanaman, diameter batang, luas daun, tingkat kehijauan daun, bobot berangkasan segar, dan bobot berangkasan kering. Sedangkan pada peubah hasil hanya berpengaruh nyata pada panjang tongkol tanpa kelobot .

Tabel 1.Rangkuman nilai $\mathrm{F}$ hitung pengaruh pengurangan $\mathrm{N}$ sintetik yang disubstitusi lumpur sawit terhadap peubah pertumbuhan dan hasil tanaman jagung manis.

\begin{tabular}{|c|c|c|}
\hline Peubah Pengamatan & F hitung & F tabel $5 \%$ \\
\hline \multicolumn{3}{|l|}{ Tinggi tanaman } \\
\hline $2 \mathrm{mst}$ & $1,28 \mathrm{~ns}$ & 2,90 \\
\hline $3 \mathrm{mst}$ & $0,69 \mathrm{~ns}$ & 2,90 \\
\hline $4 \mathrm{mst}$ & $1,07 \mathrm{~ns}$ & 2,90 \\
\hline $5 \mathrm{mst}$ & $2,14 \mathrm{~ns}$ & 2,90 \\
\hline $6 \mathrm{mst}$ & $3,38 *$ & 2,90 \\
\hline \multicolumn{3}{|l|}{ Jumlah daun } \\
\hline $2 \mathrm{mst}$ & $0,76 \mathrm{~ns}$ & 2,90 \\
\hline $3 \mathrm{mst}$ & $0,09 \mathrm{~ns}$ & 2,90 \\
\hline $4 \mathrm{mst}$ & $0,61 \mathrm{~ns}$ & 2,90 \\
\hline $5 \mathrm{mst}$ & $1,74 \mathrm{~ns}$ & 2,90 \\
\hline $6 \mathrm{mst}$ & $1,98 \mathrm{~ns}$ & 2,90 \\
\hline \multicolumn{3}{|l|}{ Diameter batang } \\
\hline $2 \mathrm{mst}$ & $0,15 \mathrm{~ns}$ & 2,90 \\
\hline $3 \mathrm{mst}$ & $1,16 \mathrm{~ns}$ & 2,90 \\
\hline $4 \mathrm{mst}$ & $0,99 \mathrm{~ns}$ & 2,90 \\
\hline $5 \mathrm{mst}$ & $1,74 \mathrm{~ns}$ & 2,90 \\
\hline $6 \mathrm{mst}$ & $3,12 *$ & 2,90 \\
\hline \multicolumn{3}{|l|}{ Kehijauan daun } \\
\hline $2 \mathrm{mst}$ & $3,49 *$ & 2,90 \\
\hline $3 \mathrm{mst}$ & $0,10 \mathrm{~ns}$ & 2,90 \\
\hline $4 \mathrm{mst}$ & $0,46 \mathrm{~ns}$ & 2,90 \\
\hline $5 \mathrm{mst}$ & $1,87 \mathrm{~ns}$ & 2,90 \\
\hline $6 \mathrm{mst}$ & $1,74 \mathrm{~ns}$ & 2,90 \\
\hline Luas Daun & $4,01^{*}$ & 2,90 \\
\hline Bobot tongkol tanpa kelobot & $2,77 \mathrm{~ns}$ & 2,90 \\
\hline $\begin{array}{l}\text { Panjang tongkol tanpa } \\
\text { kelobot }\end{array}$ & $4,12 *$ & 2,90 \\
\hline $\begin{array}{l}\text { Diameter tongkol tanpa } \\
\text { kelobot }\end{array}$ & $0,57 \mathrm{~ns}$ & 2,90 \\
\hline $\begin{array}{l}\text { Bobot tongkol berkelobot per } \\
\text { petak }\end{array}$ & $2,17 \mathrm{~ns}$ & 2,90 \\
\hline Hasil per petak & $2,55 \mathrm{~ns}$ & 2,90 \\
\hline Bobot berangkasan segar & $4,48 *$ & 2,90 \\
\hline Bobot berangkasan kering & $10,47 *$ & 2,90 \\
\hline
\end{tabular}

Keterangan :: *: berpengaruh nyata pada taraf 5\%, ns : berpengaruh tidak nyata, mst : minggu setelah tanam.

Nilai rata-rata pertumbuhan tanaman jagung manis pada pemberian pengurangan $\mathrm{N}$ sintetik yang disubstitusi lumpur sawit disajikan pada Tabel 1 dan Tabel 2.

\section{Pertumbuhan Vegetatif Jagung Manis}

Lumpur sawit merupakan salah satu sumber bahan organik yang memiliki unsur hara makro berupa $\mathrm{N}$, $\mathrm{P}$, dan $\mathrm{K}$ serta dapat dimanfaatkan sebagai pupuk organik dalam kegiatan pertanian (Nurwidayati \& Samarinda, 2017). Pengurangan N sintetik yang disubtitusi lumpur sawit berpengaruh tidak nyata pada beberapa peubah pertumbuhan dan hasil jagung manis (Tabel 1 dan Tabel 2). Salah satu faktor penyebabnya adalah pengaruh perlakuan cenderung fluktuatif terlihat pada tiap minggunya sehingga berdampak pada hasil tanaman. Hal ini tampak pada nilai rata-rata pertumbuhan dan hasil jagung manis yang berbeda-beda seperti nilai rata-rata terbesar dan terbanyak diberikan oleh perlakuan $60 \% \mathrm{~N}+40 \%$ LS sedangkan untuk nilai ratarata terkecil dan sedikit diberikan oleh perlakuan $100 \% \mathrm{~N}($ setara $138 \mathrm{~kg} / \mathrm{ha})+0 \%$ LS. Produksi jagung manis terberat yang diperoleh dalam penelitian ini dihasilkan oleh perlakuan $60 \% \mathrm{~N}+40 \% \mathrm{LS}$ sebesar 7,4 ton/ha atau $61,6 \%$ lebih rendah dari produksi jagung manis varietas Jambore.

Bahan organik yang berupa lumpur sawit pada penelitian ini memiliki kandungan C-organik $(2,05 \%)$ dan $\mathrm{N}$ total $(0,15 \%)$ masih tergolong rendah, hal ini diduga sangat mempengaruhi ketersediaan hara pada lumpur sawit yang menyebabkan tanaman tidak dapat menggunakannya. Pelapukan bahan organik yang bersumber dari lumpur sawit memerlukan waktu untuk terdekomposisi yang lebih lama agar mikroorganisme tanah dapat bekerja efektif, dan semakin lama proses dekomposisi maka pelepasan unsur hara akan semakin baik. Hal ini didukung oleh hasil penelitian Pandapotan (2017) yang menunjukkan bahwa pemberian lumpur sawit berpengaruh tidak nyata terhadap peningkatkan N-total, K-tukar, dan KTK tanah. Hasil penelitian Sari et al. (2017) menunjukkan bahwa pengurangan pupuk NPK yang digantikan oleh lumpur sawit berpengaruh tidak nyata terhadap tinggi tanaman, jumlah daun, panjang tongkol berkelobot, diameter tongkol berkelobot, berat tongkol berkelobot, berat tongkol tanpa kelobot, panjang tongkol tanpa kelobot, diameter tongkol tanpa kelobot, dan jumlah baris biji per tongkol. Hasil penelitian Sitepu \& Adiwirman (2017) menunjukkan bahwa peningkatan dosis lumpur sawit berpengaruh tidak nyata terhadap diameter tongkol berkelobot, diameter tongkol tidak berkelobot, panjang tongkol tidak berkelobot, bobot tongkol tidak berkelobot, produksi per $\mathrm{m}^{2}$, jumlah baris biji, jumlah biji per baris dan kadar gula pada biji.

Pertumbuhan vegetatif jagung manis merupakan fase awal yang ditandai dengan pertambahan ukuran dan jumlah sel dalam tanaman. Pada masa pertumbuhan vegetatif tanaman jagung manis menunjukkan respon yang berbeda pada tinggi tanaman, diameter batang, total luas daun, tingkat kehijauan daun, bobot berangkasan segar, dan bobot berangkasan kering yang dihasilkan dari tiap perlakuan. Pemberian komposisi persentase $60 \%$ $\mathrm{N}$ (setara $82,8 \mathrm{~N} \mathrm{~kg} / \mathrm{ha})+40 \% \mathrm{LS}($ setara $55,2 \mathrm{~N} \mathrm{~kg} /$ ha) $\left(\mathrm{N}_{2}\right)$ pertumbuhan tanamannya lebih unggul jika dibandingkan dengan perlakuan lainnya. Namun pada peubah tingkat kehijauan daun nilai yang paling besar justru dihasilkan oleh $100 \% \mathrm{~N}$ (setara $138 \mathrm{~kg} / \mathrm{ha}$ ) + 0 $\%$ LS seperti terlihat pada Tabel 4. 
Tabel 2. Rata-rata pertumbuhan tanaman jagung manis pada pemberian pengurangan pupuk $\mathrm{N}$ sintetik yang disubstitusi lumpur sawit.

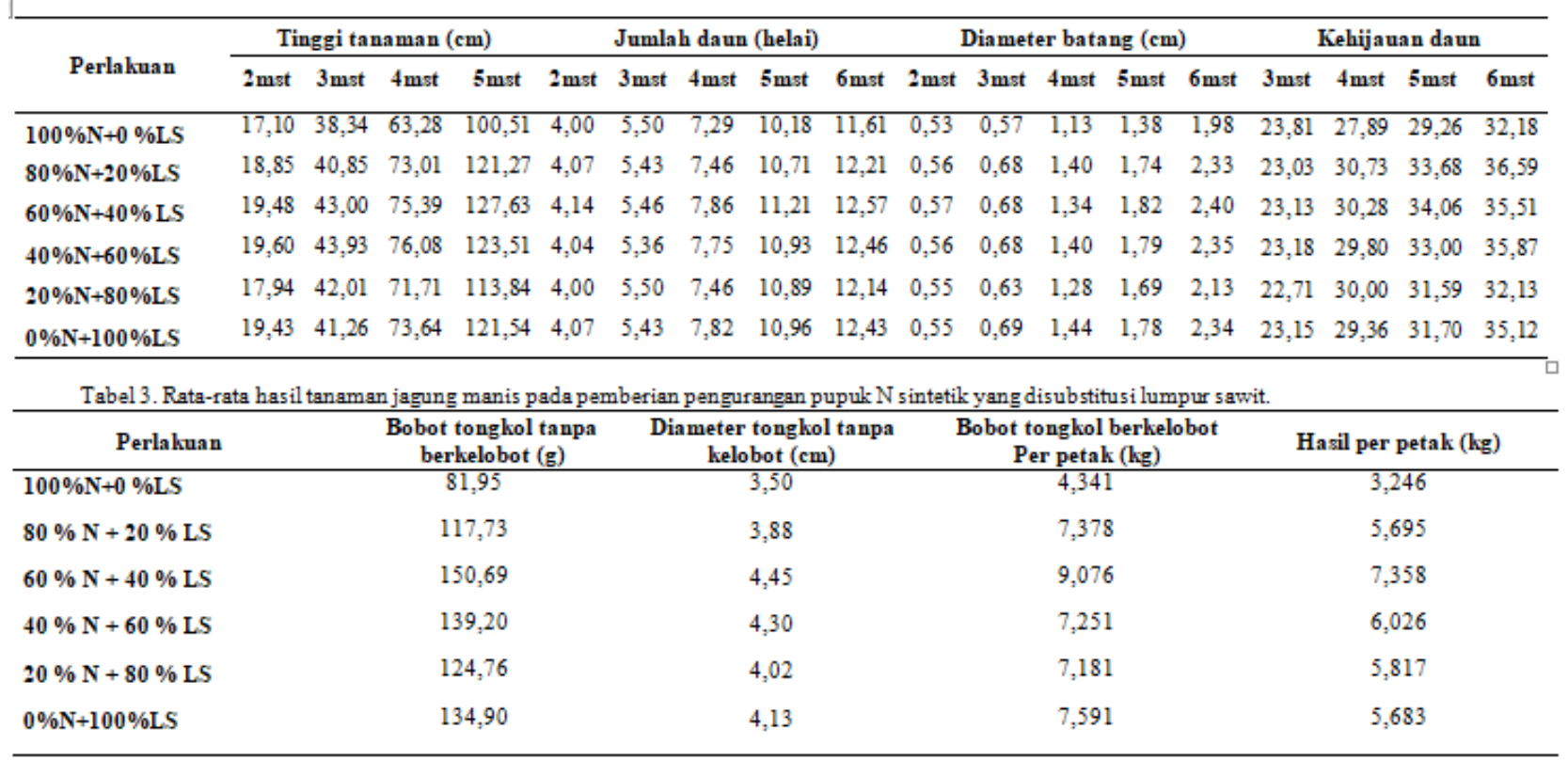

Tabel 4. Rata-rata pertumbuhan tanamanjagung manis pada pemberian pengurangan $\mathrm{N}$ sintetik yang disubstitusi lumpur sawit.

\begin{tabular}{cllllll}
\hline \multirow{2}{*}{ Perlakuan } & \multicolumn{7}{c}{ Variabel } \\
\cline { 2 - 7 } & $\begin{array}{c}\text { Tinggi } \\
\text { Tanaman } \\
6 \text { mst (cm) }\end{array}$ & $\begin{array}{c}\text { Diameter } \\
\text { Batang } \\
6 \text { mst (cm) }\end{array}$ & $\begin{array}{c}\text { Luas } \\
\text { Daun }\left(\mathrm{cm}^{2}\right)\end{array}$ & $\begin{array}{c}\text { Tingkat } \\
\text { Kehijauan } \\
\text { daun 2mst }\end{array}$ & $\begin{array}{c}\text { Bobot } \\
\text { Berangkasan } \\
\text { Segar (g) }\end{array}$ & $\begin{array}{c}\text { Bobot } \\
\text { Berangkasan } \\
\text { Kering (g) }\end{array}$ \\
\hline $\mathrm{N}_{0}$ & $139,9 \mathrm{~b}$ & $1,98 \mathrm{~b}$ & $6022,37 \mathrm{c}$ & $26,89 \mathrm{a}$ & $168,14 \mathrm{c}$ & $66,95 \mathrm{~d}$ \\
$\mathrm{~N}_{\mathrm{t}}$ & $166,1 \mathrm{a}$ & $2,33 \mathrm{ab}$ & $7213,60 \mathrm{abc}$ & $24,49 \mathrm{~b}$ & $255,40 \mathrm{bc}$ & $89,35 \mathrm{bc}$ \\
$\mathrm{N}_{2}$ & $176,4 \mathrm{a}$ & $2,40 \mathrm{a}$ & $8712,82 \mathrm{a}$ & $25,58 \mathrm{ab}$ & $375,19 \mathrm{a}$ & $136,68 \mathrm{a}$ \\
$\mathrm{N}_{3}$ & $172,8 \mathrm{a}$ & $2,35 \mathrm{a}$ & $6633,55 \mathrm{bc}$ & $25,40 \mathrm{ab}$ & $276,60 \mathrm{ab}$ & $109,55 \mathrm{~b}$ \\
$\mathrm{~N}_{4}$ & $159,5 \mathrm{ab}$ & $2,13 \mathrm{ab}$ & $5987,45 \mathrm{c}$ & $26,53 \mathrm{a}$ & $215,59 \mathrm{bc}$ & $83,62 \mathrm{~cd}$ \\
$\mathrm{~N}_{5}$ & $170,0 \mathrm{a}$ & $2,34 \mathrm{a}$ & $7826,23 \mathrm{ab}$ & $23,63 \mathrm{~b}$ & $195,03 \mathrm{bc}$ & $100,83 \mathrm{~b}$ \\
\hline
\end{tabular}

Keterangan :Angka-angka yang diikuti huruf yang sama pada kolom yang sama berbeda tidak nyata menurut BNT pada taraf $5 \%$

Tinggi tanaman merupakan salah satu indikator penting pada pertumbuhan vegetatif tanaman jagung manis terutama sebagai akumulasi hasil fotosintat yang dapat mempengaruhi nilai berat segar tanaman $(\mathrm{r}=0,59)$. Tanaman yang tertinggi dihasilkan oleh komposisi persentase $60 \% \mathrm{~N}$ (setara $82,8 \mathrm{~kg} / \mathrm{ha})+40 \% \mathrm{LS}$ (setara $55,2 \mathrm{~N} \mathrm{~kg} / \mathrm{ha}$ ) sebesar $176,4 \mathrm{~cm}$ dan terendah sebesar 139,9 cm dihasilkan oleh $100 \% \mathrm{~N}$ (setara $138 \mathrm{~kg} / \mathrm{ha})+0 \%$ LS. Penyerapan unsur hara juga dapat terjadi apabila tingkat keasaman tanah $(\mathrm{pH})$ sudah sesuai dengan syarat tumbuh jagung manis. Hasil analisis tanah akhir menunjukkan $\mathrm{pH}$ tanah sudah mengalami peningkatan dari 4,9 (masam) menjadi 5,80 (agak masam). Hal ini terjadi karena dampak pengapuran dan pemberian lumpur sawit yang mampu menaikkan nilai $\mathrm{pH}$ tanah. Pada kondisi ini akar jagung manis mampu menyerap unsur hara $\mathrm{N}$ yang berasal dari pupuk sintetik dan lumpur sawit. Peningkatan tinggi tanaman dapat berjalan dengan normal karena unsur $\mathrm{N}$ berkorelasi erat dengan perkembangan jaringan meristem aktif, sehingga sangat menentukan pertumbuhan tanaman pada luas daun $(\mathrm{r}=0,76)$. Menurut Sutanto (2002) unsur hara makro seperti N, P dan K dapat diperoleh dari penambahan bahan organik dan anorganik ke dalam tanah. Hal ini sesuai dengan hasil penelitian Pradipta et al. (2017) menunjukkan bahwa kombinasi pemberian lumpur sawit dan pupuk anorganik sesuai dosis anjuran dapat menyediakan unsur hara N, P, dan K di dalam tanah. Pemberian lumpur sawit sebanyak 15 ton/ha mampu meningkatkan unsur N pada tanah ultisol (Ramadhani, 2015). Hasil penelitian Asbur \& Purwaningrum (2015) menunjukkan bahwa bahan organik berupa lumpur sawit mampu memberikan peningkatan terhadap tinggi tanaman jagung manis. 
Sejalan dengan hasil penelitian Purba (2018) menunjukkan bahwa pemberian lumpur sawit secara tunggal sebanyak $9,45 \mathrm{~kg} / \mathrm{m}^{2}$ berpengaruh nyata terhadap peubah tinggi tanaman pada pengamatan 2 , 4, dan 6 minggu setelah tanam dan menghasilkan tinggi tanaman tertinggi sebesar $151,34 \mathrm{~cm}$.

Salah satu organ vegetatif tanaman yang dapat mempengaruhi nilai bobot segar tanaman adalah diameter batang $(\mathrm{r}=0,60)$. Hasil penelitian ini menunjukkan diameter batang jagung manis terbesar diberikan oleh perlakuan $60 \% \mathrm{~N}+40 \%$ LS sebesar $2,40 \mathrm{~cm}$. Pertambahan ukuran diameter batang jagung manis yang meningkat diduga terjadi karena akar tanaman mengabsorbsi dan mendapatkan suplai hara $\mathrm{N}, \mathrm{P}$, dan $\mathrm{K}$ yang bersumber dari komposisi persentase $60 \% \mathrm{~N}$ (setara $82,8 \mathrm{~kg} / \mathrm{ha}$ ) $+40 \%$ LS (setara $55,2 \mathrm{~N}$ $\mathrm{kg} / \mathrm{ha}$ ) di dalam tanah melalui bulu-bulu akar yang aktif mencari hara terdekat. Hara $\mathrm{N}$ yang diadsorbsi akar tersebut berfungsi untuk memacu pembelahan sel sedangkan unsur K berfungsi sebagai penyusun bagian tanaman terutama perkembangan jarin gan meristem dalam pembentukan batang (Lakitan, 1996). Unsur makro tersebut memegang peranan penting dalam metabolisme tanaman pada fase pertumbuhan vegetatif (Sutanto, 2002). Hal ini didukung oleh hasil penelitian Sitepu \& Adiwirman (2017) menunjukkan bahwa pemberian pupuk NPK dengan dosis tertinggi sebanyak $300 \mathrm{~kg} /$ ha berpengaruh nyata terhadap diameter batang dan menghasilkan diameter batang jagung manis sebesar 2,93 cm.

Bertambahnya ukuran tinggi tanaman berkorelasi positif terhadap luas daun yang dihasilkan tanaman $(\mathrm{r}=0,71)$. Semakin luas daun jagung manis maka perolehan cahaya sebagai energi utama lebih optimal. Pada pemberian komposisi persentase $60 \% \mathrm{~N}$ (setara $82,8 \mathrm{~kg} / \mathrm{ha}$ ) $+40 \% \mathrm{LS}$ (setara $55,2 \mathrm{~N} \mathrm{~kg} / \mathrm{ha}$ ) menghasilkan nilai luas daun rata-rata sebesar $8712,82 \mathrm{~cm}^{2}$. Hal ini dapat terjadi karena akar tanaman dapat menyerap hara $\mathrm{N}$ tersedia di dalam tanah yang bersumber dari pupuk $\mathrm{N}$ sintetik dan lumpur sawit serta ditranslokasikan ke seluruh bagian tanaman jagung manis. Hasil penelitian Irawan et al. (2017) menunjukkan bahwa kombinasi bahan organik dan anorganik yang berimbang berpengaruh nyata terhadap tinggi tanaman, diameter batang, luas daun, dan berat kering total tanaman.

Bertambahnya daun baru dapat meningkatkan jumlah daun pada tanaman yang berakibat bertambahnya luas daun sehingga dapat meningkatkan fotosintesis dan penyerapan cahaya oleh daun (Simanihuruk, 2001 ; Abrar et al., 2018). Semakin hijau warna daun maka jumlah klorofil pada tanaman semakin banyak. Pembentukan fotosintat dapat mendorong kecepatan pembentukan organ-organ tanaman seperti daun (Sulistyaningsih et al., 2005). Hasil penelitian ini menunjukkan bahwa tingkat kehijauan daun yang paling besar dihasilkan oleh $100 \% \mathrm{~N}$ (setara 138 $\mathrm{kg} / \mathrm{ha})+0 \%$ LS yaitu 26,89. Peningkatan hijau daun ini diduga terjadi karena dampak pengapuran yang mampu menaikkan $\mathrm{pH}$ tanah sebesar 5,80 dan juga diikuti dengan membaiknya kondisi perkembangan dan pertumbuhan perakaran jagung manis. Menurut Foth (1984) kelimpahan hara N pada tanaman juga mendorong pertumbuhan vegetatif yang cepat termasuk perkembangan daun, batang lebih besar dan daun berwarna hijau tua. Menurut Irmayani (2013) bahwa hara $\mathrm{N}$ merupakan hara yang digunakan untuk penyedia nutrisi tanaman, dan merupakan komponen utama penyusun klorofil, protoplasma, dan protein. Unsur $\mathrm{N}$ berperan banyak dalam proses fisiologi tanaman yaitu pada pertumbuhan vegetatif dan merangsang pertumbuhan di atas tanah dengan memberikan warna hijau pada daun. Namun demikian, apabila jumlah unsur $\mathrm{N}$ yang diberikan berlebihan maka dapat menghambat proses pembungaan dan pengisian biji bahkan dapat mengundang hama dan penyakit. Hal ini sejalan dengan hasil penelitian Pangaribuan et al. (2017) yang menunjukkan bahwa kombinasi pupuk anorganik tunggal dan pupuk hayati berpengaruh nyata pada peubah pertumbuhan, hasil jagung manis dan populasi mikroba semakin banyak.

Akumulasi total selama masa pertumbuhan vegetatif menjadi satu yaitu pada bobot berangkasan segar tanaman. Bobot berangkasan segar tanaman jagung manis terberat rata-rata sebesar $375,19 \mathrm{~g}$ dihasilkan oleh perlakuan $60 \% \mathrm{~N}+40 \% \mathrm{LS}$. Hal ini terjadi karena tanaman mengalami pertumbuhan yang normal seiring bertambahnya tinggi tanaman dan diameter batang selama masa vegetatif berlangsung. Komposisi persentase $60 \% \mathrm{~N}$ (setara $82,8 \mathrm{~kg} / \mathrm{ha}$ ) + $40 \%$ LS (setara 55,2 N kg/ha) sebagai pemasok bahan organik dan sumber unsur hara $\mathrm{N}$ diduga mampu menyediakan unsur hara lebih banyak yang dibutuhkan tanaman selama masa vegetatif dan generatif. Hasil penelitian Sitohang \& Utomo (2018) menunjukkan bahwa aplikasi residu biochar tongkol jagung diperkaya amonium sulfat pada $\mathrm{pH}$ tanah yang berbeda berpengaruh nyata pada sifat kimia tanah yaitu KTK tanah dan N-Total tanah.

Bobot berangkasan kering tanaman merupakan akibat efisiensi penyerapan dan pemanfaatan energi matahari yang tersedia sepanjang musim tanam dan tidak mengandung air (Gardner et al., 1985). Hasil penelitian ini menunjukkan bobot berangkasan kering terberat sebesar 136,68 g dihasilkan oleh perlakuan $60 \% \mathrm{~N}+40 \%$ LS. Hal ini terjadi karena penyerapan hara $\mathrm{N}, \mathrm{P}$ dan $\mathrm{K}$ yang bersumber dari komposisi persentase $60 \% \mathrm{~N}$ (setara $82,8 \mathrm{~kg} / \mathrm{ha}$ ) $+40 \%$ LS (setara $55,2 \mathrm{~N} \mathrm{~kg} / \mathrm{ha}$ ) serta fotosintat yang dihasilkan langsung disebarkan ke seluruh bagian tanaman. Menurut Kresnatita et al. (2012) pemupukan N yang cukup dapat mendukung pertumbuhan setiap organ tanaman menjadi sempurna dan fotosintat yang terbentuk akan meningkat, serta dapat mendorong 
produksi tanaman yang maksimal. Hasil penelitian Seipin et al. (2016) menunjukkan bahwa pemberian bahan organik pada jagung manis berpengaruh nyata terhadap tinggi tanaman, laju pertumbuhan tanaman, diameter batang, berat kering tanaman dan panjang tongkol tanpa kelobot.

\section{Pertumbuhan Generatif Jagung Manis}

Panjang tongkol tanaman jagung manis merupakan indikator hasil dari sebuah penelitian. Menurut deskripsi varietas jambore memiliki ukuran panjang tongkol jagung manis rata-rata $18,7 \mathrm{~cm}-21,4 \mathrm{~cm}$. Sedangkan rata-rata panjang tongkol tanpa kelobot jagung manis pada penelitian ini sebesar $17,93 \mathrm{~cm}$ yang dihasilkan oleh komposisi persentase $60 \% \mathrm{~N}$ (setara $82,8 \mathrm{~kg} / \mathrm{ha}$ ) $+40 \%$ LS (setara $55,2 \mathrm{~N} \mathrm{~kg} / \mathrm{ha}$ ) dan belum memenuhi kriteria berdasarkan deskripsi jagung manis. Setiap perlakuan menghasilkan perilaku yang sama seiring berkurangnya dosis pupuk $\mathrm{N}$ sintetik yang diberikan dan disubtitusi lumpur sawit. Hal ini diduga terjadi karena proses pelepasan hara yang bersumber dari lumpur sawit sudah maksimal sehingga unsur hara dapat diperoleh oleh akar tanaman dan digunakan untuk pembentukan tongkol.

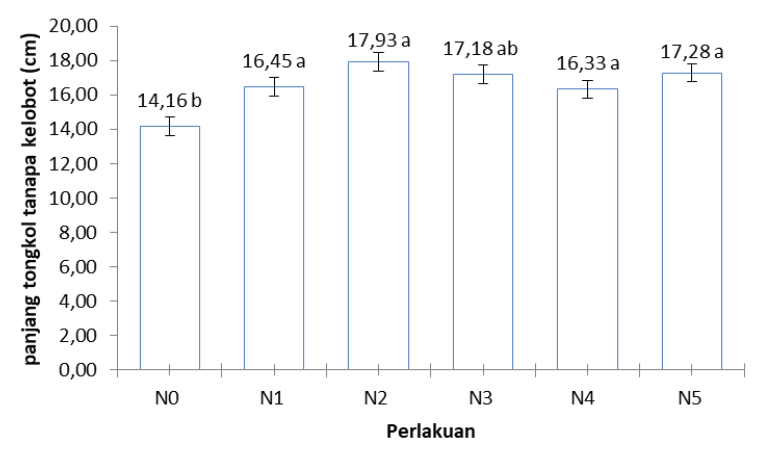

Gambar 1. Rata-rata panjang tongkol tanpa kelobot tanaman jagung manis pada pemberian pengurangan $\mathrm{N}$ sintetik yang disubstitusi lumpur sawit pada seluruh perlakuan.

Bertambahnya ukuran panjang tongkol jagung manis diperoleh dari unsur hara makro berupa $\mathrm{N}, \mathrm{P}$ dan $\mathrm{K}$ yang diserap oleh akar tanaman. Hal ini dikarenakan bobot berangkasan kering tanaman berkorelasi positif terhadap panjang tongkol tanpa kelobot $(\mathrm{r}=0,66)$ yang dihasilkan dari akumulasi unsur hara yang bersumber dari komposisi persentase 60 $\% \mathrm{~N}$ (setara $82,8 \mathrm{~kg} / \mathrm{ha})+40 \%$ LS (setara $55,2 \mathrm{~N}$ $\mathrm{kg} / \mathrm{ha}$ ) dan fotosintat pada seluruh organ vegetatif selama fase pertumbuhan dan generatif berlangsung. Hasil analisis tanah akhir menunjukkan kandungan hara rata $\mathrm{N}$ sebesar 0,35 $\%$ (sedang), kandungan $\mathrm{P}$ sebesar 8,90 ppm (tinggi) dan $\mathrm{K}$ sebesar 0,38 me/100 (rendah). Berdasarkan data tersebut jagung manis sudah memiliki sumber hara makro yang bisa dimanfaatkan selama masa pertumbuhan. Ketersediaan unsur hara juga erat kaitannya dengan waktu tanam berikutnya, karena lumpur sawit pada musim tanam pertama diduga belum maksimal memberikan pengaruh pada hasil terutama panjang tongkol jagung manis. Unsur $\mathrm{N}$ merupakan komponen utama dalam proses sintesa protein. Apabila sintesa berlangsung normal maka akan berkorelasi positif terhadap peningkatan panjang tongkol jagung manis. Unsur P juga sangat menentukan hasil tanaman karena perannya dibutuhkan untuk pembentukan pati dalam biji. Unsur $\mathrm{K}$ di dalam tanaman berfungsi untuk mentranslokasi gula, aktifitas enzim dan pergerakan stomata. Peningkatan bobot dan kandungan gula pada tongkol terjadi karena fotosintesis meningkat yang menghasilkan fotosintat dan ditranslokasikan ke bagian tongkol jagung manis (Haris \& Krestiani, 2009)

Hasil penelitian Adil et al. (2006) menunjukkan bahwa efisiensi serapan $\mathrm{N}$ tertinggi diperoleh dari pemberian kompos kotoran ayam tanpa urea pada musim tanam pertama yang menghasilkan bobot kering tanaman tertinggi, tetapi pada musim tanam selanjutnya kompos kotoran ayam yang dikombinasikan dengan urea memberikan bobot kering tanaman tertinggi. Menurut Rachman et al. (2008) kombinasi antara pupuk organik dan anorganik dapat memenuhi kebutuhan unsur $\mathrm{N}$ dan $\mathrm{P}$ yang berperan penting dalam pembelahan sel dan pembentukan bunga dan biji. Hasil penelitian Suratmini (2009) menunjukkan bahwa pemupukan $\mathrm{N}$ sebesar $300 \mathrm{~kg} /$ hamenghasilkan panjang tongkol jagung manis sebesar $17,3 \mathrm{~cm}$. Hal ini didukung oleh hasil penelitian Subardja (2017) yang menunjukkan bahwa pemberian $\mathrm{N}$ sebesar $300 \mathrm{~kg} / \mathrm{ha}$ dan 2 ton kompos/ha menghasilkan rata-rata panjang tongkol sebesar $16,7 \mathrm{~cm}$.

\section{KESIMPULAN}

Hasil penelitian menunjukkan bahwa petak yang dipupuk dengan $60 \%$ pupuk sintetik $+40 \%$ LS menghasilkan tinggi tanaman $(176,4 \mathrm{~cm})$, diameter batang $(2,40 \mathrm{~cm})$, luas daun $\left(8712,82 \mathrm{~cm}^{2}\right)$, bobot berangkasan segar $(375,19 \mathrm{~g})$, bobot berangkasan kering (136,68 g), dan panjang tongkol tanpa kelobot $(17,93 \mathrm{~cm})$ tertinggi. Namun demikian, hasil tongkol tanpa kelobot tertinggi hanya mencapai $61,6 \%$ dari potensi hasil varietas jagung manis yang digunakan.

\section{DAFTAR PUSTAKA}

Abrar, A. K., Ashaq, H., Manzoor, A., Ganai, Z., Rashid \& Zahoor, A.D. (2018). Response of sweet corn hybrid to transplanting dates and nitrogen levels under temperate conditions. Int. J. Curr. Microbiol. App. Sci, 7(4), 1284-1291.

Adil, W. H., Sunarlim, N. \& Roostika, I. (2006). Pengaruh tiga jenis pupuk nitrogen terhadap tanaman sayuran. Biodiversitas, 7(1), 77-80. 
Agustyari, N. K., Antara, I. \& Anggreni, I.G.A.A.L (2013). Perbandingan pendapatan usahatani jagung manis dan padi di Subak Delod Sema Padang Galak Desa Kesiman Petilan Kecamatan Denpasar Timur. Journal of Agribusiness and Agritourism, 2(4), 224-235.

Ariyanto, S. E. (2011). Perbaikan kualitas pupuk kandang sapi dan aplikasinya pada tanaman jagung manis (Zea mays saccharata Sturt). Jurnal Sains dan Teknologi, 4(2), 164-176.

Asbur, Y \& Purwaningrum, Y. (2015). Optimalisasi produksi jagung manis dengan pemberian pupuk berimbang organik dan anorganik. Jurnal Pertanian Tropik, 2(3), 211-219.

Badan Penelitian dan Pengembangan Pertanian. (2005). Analisis Kimia Tanah, Tanaman, Air dan Pupuk. Penerbit Balai Penelitian Tanah. Departemen Pertanian, Bogor.

Badan Pusat Statistik. (2015). Produksi Nasional Jagung. 2014. http://www.bps.go.id. Diakses pada 20 Oktober 2017.

Badan Pusat Statistik. 2017. Produksi Nasional Jagung. 2015-2016. http://www.bps.go.id. Diakses pada 20 Oktober 2017.

Beckingham, C. 2007. Commodity growing guidesSweet corn. NSW Department of Primary Industries. http://www.dpi.nsw.gov.au/agriculture/

horticulture/ vegetables/commodity/sweet-corn, NSW, Australia. Diakses pada 3 September 2018.

Darmawati, J. S., Nursamsi \& Siregar, A.R. (2014). Pengaruh pemberian limbah padat (sludge) kelapa sawit dan pupuk organik cair terhadap pertumbuhan dan produksi tanaman jagung manis (Zea mays saccharata). AGRIUM, 19(1), 59-67.

Foth, H.D. (1984). Soil Science. Penerbit John Wiley. Library Australia. Diterjemahkan oleh Endang, D. P. L., Retno, D. dan Trimulatsih, R. 1988. Gadjah Mada University Press., Yogyakarta.

Gardner, F.P., Pearce, R.B. \& Mitchell, R.L. (1985). Physiology of Crops Plant. Iowa State. Diterjemahkan oleh Susilo, H., Subiyanto \& Handayani. (1991). Universitas Indonesia, UI Press., Jakarta.

Handajaningsih, M. (2010), Growth analysis of sweet corn and its corelation to the yield at different rate application of palm oil sludge compost. Proceeding International Seminar. Bandar Lampung, Lampung 22-23 Juni 2010.

Haris, A. \& Krestiani, V. (2009). Studi pemupukan kalium terhadap pertumbuhan dan hasil jagung manis (Zea mays saccharata Sturt) Varietas Super bee. Sains dan Teknologi, 2(1), 1-5.
Irawan, J., Sitawati, S. \& Sudiarso, S. (2017). Pengaruh macam bahan organik dan pupuk $\mathrm{N}$ pada pertumbuhan dan hasil jagung manis (Zea mays saccharata Sturt). Jurnal Produksi Tanaman, 5(11), 1816-1825.

Irmayani, T. (2013). Pengaruh pemberian pupuk nitrogen terhadap timbulnya penyakit daun tanaman jagung (Zea mays L.) pada beberapa varietas di lapangan. Skripsi. Universitas Sumatera Utara, Medan.

Jenny, M.U \& Suwadji, E. (1999). Pemanfaatan Limbah Minyak Sawit (Sludge) sebagai Pupuk Tanaman dan Media Jamur Kayu. BATAN, Bogor.

Kresnatita, S., Koesriharti, K. \& Santoso, M. (2012). Pengaruh rabuk organik terhadap pertumbuhan dan hasil tanaman jagung manis. The Indonesian Green Technology Journal, 1(3), 8-17.

Lakitan, B. (1996). Dasar-Dasar Fisiologi Tumbuhan. PT. Radja Grafindo Persada, Jakarta.

Lestari, A.P. (2009). Pengembangan pertanian berkelanjutan melalui subtitusi pupuk anorganik dengan pupuk organik. Jurnal Agronomi, 13(1), $38-44$.

Made, U. (2010). Respons berbagai populasi tanaman jagung manis (Zea mays saccharata Sturt.) terhadap pemberian pupuk urea. Jurnal Agroland, 17(2), 138-143.

Marpaung, A.E. (2014). Pemanfaatan pupuk organik padat dan pupuk organik cair dengan pengurangan pupuk anorganik terhadap pertumbuhan tanaman jagung (Zea mays L). Jurnal Saintech, 6 (4), 8-15.

Muamar, M., Triyomo, S., Tusi, A. \& Rosadi, B. (2012). Analysis of water balance of corn (Zea mays) in Bandar Lampung. Jurnal Teknik Pertanian Lampung, 1(1), 1-10.

Nursanti, I., Budianta, D., Napoleon, A. \& Parto, Y. (2013). Pengolahan limbah cair pabrik kelapa sawit kolam anaerob sekunder I menjadi pupuk organik melalui pemberian zeolit. Prosiding Seminar Nasional Sains dan Teknologi $V$. Lembaga Penelitian Universitas Lampung. 1920 November 2013.

Nurwidayati, T. \& Samarinda, B.I. (2017). Pemanfaatan endapan limbah cair pabrik kelapa sawit (LCPKS) dan abu tandan buah kosong kelapa sawit (TKKS) sebagai pupuk organik tablet. Prosiding Seminar Nasional Ke 1 Tahun 2017. Samarinda.

Pandapotan, C.D., Mukhlis, M. \& Marbun, P. (2017). Pemanfaatan limbah lumpur padat (Sludge) pabrik pengolahan kelapa sawit sebagai alternatif penyediaan unsur hara di tanah ultisol. Jurnal Agroekoteknologi Universitas Sumatera Utara, 5 (2), 271-276. 
Pangaribuan, D. H., Hendarto, K. \& Prihartini, K. (2017). Pengaruh pemberian kombinasi pupuk anorganik tunggal dan pupuk hayati terhadap pertumbuhan dan produksi tanaman jagung manis (Zea mays saccharata Sturt) serta populasi mikroba tanah. Jurnal Floratek, 12(1), 1-9.

Pradipta, M., Armain, A. \& Amri, A.I. (2017). Kombinasi pemberian limbah padat (sludge) pabrik kelapa sawit dan pupuk N, P dan K pada tanaman jagung manis (Zea mays Var saccharata Sturt). Jurnal Online Mahasiswa Fakultas Pertanian Universitas Riau, 4(2), 1-11.

Pramana, N.D. \& Amri, A.I. (2016). Pengaruh sludge limbah kelapa sawit dan pupuk NPK Mg (15: 15: 6: 4) dalam media tanam ultisol terhadap pertumbuhan bibit kelapa sawit (Elaeis guineensis Jacq) di main nursery. Jurnal Online Mahasiswa Fakultas Pertanian Universitas Riau, 3(1), 1-16.

Prasetyo, W., Santoso. M. \& Wardiyati, T. (2013). Pengaruh beberapa macam kombinasi pupuk organik dan anorganik terhadap pertumbuhan dan hasil tanaman jagung manis (Zea mays saccharata Sturt). Jurnal Produksi Tanaman, 1 (3), 79-86.

Purba, D. W. (2018). Pengaruh pemberian sludge kelapa sawit dan berbagai jenis pupuk kandang terhadap pertumbuhan dan produksi jagung manis (Zea mays saccharata Sturt). Jurnal Pionir, 2(4), 1-12.

Rachman, I. A., Djuniwati, S. \& Idris, K. (2008). Pengaruh bahan organik dan pupuk NPK terhadap serapan hara dan produksi jagung di Inceptisol Ternate. Jurnal Tanah dan Lingkungan, 10(1), 7-13.

Said, E. G. (1996). Penanganan dan Pemanfatan Limbah Kelapa Sawit. Trubus. Agriwidya, Bogor.

Santoso, I.A. (2011). Serat pangan (dietary fiber) dan manfaatnya bagi kesehatan. Jurnal Magistra, 23 (75), 35-40

Sari D. P., Gusmara, H. \& Simanihuruk, B.W. (2017). Pertumbuhan dan hasil jagung manis (Zea mays saccharata) dengan pengurangan pupuk NPK yang digantikan dengan lumpur kelapa sawit (sludge) pada tanah ultisol. Jurnal Agritrop, 15(1), 138-150.

Seipin, M., Sjofjan, J. \& Ariani, E. (2016). Pertumbuhan dan produksi tanaman jagung manis (Zea mays saccharata Sturt) pada lahan gambut yang diberi abu sekam padi dan kompos jerami padi. Jurnal Online Mahasiswa Fakultas Pertanian Universitas Riau, 3(2), 1-15.
Simanihuruk, B. W. (2001). Analisis pertumbuhan tanaman jagung manis (Zea mays saccharata) pergeseran komposisi gulma pada beberapa jarak tanam. JIPI, 3(1), 25-30.

Sitepu, A. \& Adiwirman, A. (2017). Respon pertumbuhan dan produksi jagung manis (Zea mays Var. saccharata Sturt) terhadap limbah padat pabrik kelapa sawit dan NPK. Jurnal Online Mahasiswa Fakultas Pertanian Universitas Riau, 4(2), 1-15.

Sitohang, E. A. \& Utomo, W.H. (2018). Pengaruh residu biochar tongkol jagung diperkaya amonium sulfat terhadap beberapa sifat tanah dan pertumbuhan tanaman jagung manis di $\mathrm{pH}$ tanah yang berbeda. Jurnal Tanah dan Sumberdaya Lahan, 5(1), 713-720.

Subardja, V. (2017). Karakteristik pertumbuhan dan hasil jagung manis di lahan marginal dengan dosis pemupukan $\mathrm{N}$ yang berbeda. Jurnal Agrotek Indonesia, 2(1), 7-12.

Sulistyaningsih, E., Kurniasih, B. \& Kurniasih, E. (2005). Pertumbuhan dan hasil caisin pada berbagai warna sungkup plastik. Ilmu Pertanian, 12(1), 65-76.

Suratmini, P. (2009). Kombinasi pemupukan urea dan pupuk organik pada jagung manis di lahan kering. Jurnal Balai Pengkajian Teknologi Pertanian, 28(2), 83-88.

Susilo, D. E. H. (2015). Identifikasi nilai konstanta bentuk daun untuk pengukuran luas daun metode panjang kali lebar pada tanaman hortikultura di tanah gambut. Jurnal Anterior, 14(2), 139-146.

Sutanto, R. (2002). Penerapan Pertanian Organik. Penerbit Kanisius, Yogyakarta.

Syofia, I., Munar, A. \& Sofyan, M. (2015). Pengaruh pupuk organik cair terhadap pertumbuhan dan hasil dua varietas tanaman jagung manis (Zea mays saccharata Sturt). Jurnal Agrium, 18(3), 208-218.

Syukur, M. \& Rifianto, S.P.A. (2013). Jagung Manis. Penebar Swadaya, Jakarta.

Wahyono, S., Sahwan, F.L., Martono, J.H. \& Suyanto, F. (2008). Tinjauan terhadap perkembangan penelitian pengolahan limbah padat pabrik kelapa sawit. Jurnal Teknik Lingkungan. Edisi khusus, 64-74.

Yulianti, Y., Hadie, J. \& Nisa, C. (2016). Tanggapan pertumbuhan dan hasil jagung manis (Zea mays saccharata Sturt.) terhadap pemberian kapur dan pupuk kandang kotoran ayam. Daun: Jurnal Ilmiah Pertanian dan Kehutanan, 3(2), 108-121. 